\title{
Foreword \\ to the First Edition
}

ond

The music of fourteenth century Italy has attracted so many scholars both here and abroad, especially during the past three decades, that the enthusiasm they have generated perhaps matches the ardor and zeal of the early trecentists themselves when they first began to set their madrigali amorosi to soave et dolci melodie. A fascinating period was the Trecento, and, moreover, equally fascinating to the cultured fourteenth and fifteenth century gentleman collector, for many of the compositions were copied and preserved in libraries beyond the Italian border.

Thanks to the ever-growing number of philologists, musicologists, and musicologically trained performers, who have dedicated themselves to the Italian Ars Nova, we have been provided with excellent critical editions and fine recordings. But musicological research continues. Much has happened since the pioneering works of Johannes Wolf and Friedrich Ludwig first appeared at the beginning of the twentieth century and opened the vault to the fourteenth-century treasures of Italian music. Since then many papers have been read before national and international musicological congresses; articles have been published on specific practices; translations of fourteenth-century treatises are now available as are studies on Italian notation, composers, and their music; manuscript inventories have appeared in our musicological journals and simplified their identification; and recently, complete collections have been begun by Nino Pirrotta for the American Institute of Musicology and by Leo Schrade and this writer for Editions de l'Oiseau Lyre.

To these various facets such writers as Heinrich Besseler, Leonard Ellinwood, Kurt von Fischer, Federico Ghisi, Annamarie von Königslow, Susan Le Clercx, Ettore LiGotti, Nino Pirrotta, Gilbert Reaney, Claudio Sartori, Leo Schrade, and myself (to mention but a few) have contributed to the expanding Trecento edifice. In the face of this wealth of informa- 
tion concerning the music and literature of this period, we are overwhelmed yet delighted when still another publication comes to our attention. How to keep the facts straight and in their proper niches has no doubt been asked by many a student and teacher.

Fortunately, this situation was foreseen by Viola Hagopian in 1961 when she embarked on the tortuous path and undertook the laborious role by examining the contents of these publications dealing with the Italian Trecento. Each item was duly noted, briefly described, and entered under its proper classification. Once the reader has familiarized himself with the method of classification, he will certainly find this bibliography a trustworthy and useful guide, a time-saving tool, and a welcome addition to Trecento studies. Mrs. Hagopian has indeed rendered a much-needed service to the cause of musicology.

W. Thomas Marrocco

1964 